\title{
Incidence of chronic heart failure with preserved left ventricular ejection fraction in patients with hypertension and isolated mild diastolic dysfunction
}

\author{
Halina Brzyżkiewicz', Ewa Konduracka², Grzegorz Gajos², Marianna Janion \\ 1 2nd Department of Cardiology, Świętokrzyskie Centre of Cardiology, Kielce, Poland \\ 2 Department of Coronary Artery Disease and Heart Failure with the Intensive Cardiac Care Unit, \\ Jagiellonian University Medical College, John Paul II Hospital, Kraków, Poland \\ 3 2nd Department of Cardiology, Świętokrzyskie Centre of Cardiology, Department of Health Sciences, Jan Kochanowski University in Kielce, Poland
}

\section{KEY WORDS}

heart failure with preserved ejection fraction, impaired left ventricular relaxation
Correspondence to: Halina Brzyżkiewicz, MD, PhD, II Klinika Kardiologii, Świętokrzyskie Centrum Kardiologii, ul. Grunwaldzka 45, 25-736 Kielce, Poland phone: +48413671456, e-mail:brzyzkiewicz@op.pl Received: November 24, 2015 Revision accepted: December 7, 2015.

Published online: January 22, 2016 Conflict of interest: none declared. Pol Arch Med Wewn. 2016; 126 (1-2): $12-18$

Copyright by Medycyna Praktyczna Kraków 2016

\section{ABSTRACT}

INTRODUCTION Heart failure (HF) with preserved ejection fraction (HFPEF) is still a challenge in clinical practice. The prognosis of patients with HFPEF is similar to or only slightly better than that of patients with HF with reduced ejection fraction (HFREF). Impaired relaxation is the mildest form of diastolic dysfunction, which should not be accompanied by symptoms of HFPEF.

OBJECTIVES The aim of the study was to assess the incidence of chronic HFPEF in patients with hypertension and isolated mild diastolic dysfunction.

PATIENTS AND METHODS It was a cross-sectional study including 210 patients (mean age, $56.11 \pm 6.24$ years; women, 58\%) with isolated abnormalities of left ventricular relaxation and arterial hypertension. In addition, we identified patients with type 2 diabetes to compare the incidence of HFPEF between patients with and without diabetes. HFPEF was diagnosed when clinical symptoms of HF were present simultaneously with echocardiographic markers of elevated left ventricular diastolic pressure, pulmonary congestion on chest X-ray, or elevated serum brain natriuretic peptide (BNP) levels.

RESULTS HFPEF was diagnosed in $42 \%$ of the patients with impaired relaxation. An elevated left atrial volume index $\left(>34 \mathrm{ml} / \mathrm{m}^{2}\right)$ was observed in $38 \%$ of the patients; E/e' ratio exceeding 8 , in $37 \%$; elevated BNP levels, in $39 \%$; and pulmonary congestion on chest X-ray, in $41 \%$. Independent predictors of HFPEF were age, systolic blood pressure of $140 \mathrm{mmHg}$ or higher, type 2 diabetes, coronary artery disease, and an estimated glomerular filtration rate of less than $60 \mathrm{ml} / \mathrm{min} / 1.73 \mathrm{~m}^{2}$. In diabetic patients, a positive correlation was found between an insulin dose ( $>80$ units/day) and BNP levels.

conclusions Patients with isolated relaxation abnormalities constitute a clinically heterogeneous group because some of these individuals present with symptoms of HFPEF and a simultaneous increase in BNP levels. Therefore, the question of whether diastolic dysfunction is mild should be readdressed, and it should be emphasized that these patients have a serious prognosis with the risk of HF. In diabetic patients, a positive correlation between high insulin doses and BNP levels requires further research.

INTRODUCTION In approximately $30 \%$ to $50 \%$ of newly diagnosed patients with heart failure (HF), systolic function assessed by measuring the left ventricular ejection fraction (LVEF) is normal or near normal. These patients have diastolic HF, known today as HF with preserved ejection fraction (HFPEF), which may be either isolated or, more often, accompanies systolic HF with reduced ejection fraction (HFREF). The etiology of HFPEF is often complex. Apart from old age, its common causes include hypertension, obesity, left ventricular (LV) systolic dysfunction, chronic 
coronary artery disease (CAD), hypertrophic cardiomyopathy, congenital heart defects associated with ventricular hypertrophy, and diabetes. ${ }^{1-15}$

According to the European Society of Cardiology (ESC), the diagnosis of HFPEF requires 4 criteria to be met: the presence of signs and symptoms typical of HF, normal or only mildly reduced LVEF, no LV dilation, and relevant structural heart disease or left ventricular diastolic dysfunction (or both).

The prognosis of patients with HFPEF is similar to or slightly better than that of patients with HFREF and has not improved over the recent decades. ${ }^{3,4}$ The full onset of HFPEF is preceded by a clinically asymptomatic stage characterized only by echocardiographic signs of diastolic dysfunction. Based on the echocardiographic pattern, 3 grades of diastolic dysfunction have been distinguished: mild, called an "abnormal relaxation pattern"; moderate, called a "pseudonormal filling pattern"; and severe, known as a "restrictive filling pattern". An abnormal relaxation pattern without systolic dysfunction is believed to be the earliest and mildest form of diastolic dysfunction that generally should not lead to HFPEF. This common belief makes clinicians less alert to the possible signs and symptoms of HFPEF because they do not suspect it in their patients. However, our previous unpublished findings indicate that patients with an abnormal relaxation pattern constitute a diverse group and differ not only in clinical symptoms but also in the results of noninvasive cardiac tests conducted to evaluate myocardial function. This indicates the need not only to intensify the causative treatment of HFPEF but also to question the general belief that impaired relaxation is a relatively "mild" form of diastolic dysfunction.

The aim of the study was to assess the relationship between the incidence of chronic HF$\mathrm{PEF}$ in patients with hypertension and isolated relaxation abnormalities (without systolic dysfunction) and hypertension.

PATIENTS AND METHODS It was a crosssectional cohort study. At baseline, the study included 410 hypertensive patients treated at an outpatient cardiac clinic of the Świętokrzyskie Centre of Cardiology in Kielce, Poland, who gave their informed consent to participate in the study. The study was approved by a local bioethics committee. In all patients, hypertension was diagnosed before enrollment to the study as systolic blood pressure of $140 \mathrm{mmHg}$ or higher and/or diastolic blood pressure of $90 \mathrm{mmHg}$ or higher on at least 2 separate measurements, or hypotensive therapy initiated due to elevated blood pressure. ${ }^{16}$ At the time of entry, all participants were treated with antihypertensive agents.

The inclusion criteria were as follows: 1) an abnormal relaxation pattern on echocardiography (an E/A ratio of less than 1.0 and deceleration time [DT] exceeding $200 \mathrm{~ms}$ in hypertensive patients younger than 50 years of age, and an E/A ratio of less than 0.75 and DT exceeding $220 \mathrm{~ms}$ in patients aged 50 years or older); 2) normal global LVEF on echocardiography ( $\geq 50 \%)$; and 3) lack of conditions that might hamper the assessment of diastolic dysfunction, such as tachycardia (heart rate exceeding $100 \mathrm{bpm}$ ), atrial fibrillation or atrial flutter, or the presence of a cardiac pacemaker.

We excluded patients with global systolic dysfunction $(\mathrm{n}=40)$ and those in whom diastolic function could not be determined ( $n=159)$. Other exclusion criteria were as follows: refusal to participate in the study $(\mathrm{n}=1)$, anemia (hemoglobin levels, $<13 \mathrm{~g} / \mathrm{dl}$ for men and $<12 \mathrm{~g} / \mathrm{dl}$ for women), pulmonary diseases with dyspnea, vascular disease with edema, structural valvular heart defects, constrictve pericarditis, and uncontrolled hyperthyroidism and hypothyroidism. The final study sample included 210 patients with hypertension and isolated abnormalities of LV relaxation. Because diabetic patients are at higher risk of HF, we identified 140 patients with type 2 diabetes ( $68 \%$ of the study group) in order to assess the incidence of HFPEF in this patient group.

All patients underwent a full echocardiographic study (VIVID 9 ultrasound machine, GE, BT 12, Harten, Norway). The echocardiographic measurements were performed according to the guidelines of the American Society of Echocardiography and European Association of Echocardiography. ${ }^{2,17}$ The echocardiographic markers of elevated LV end-diastolic pressure included an E/e' exceeding 8 and left atrial volume index (LAVI) exceeding $34 \mathrm{ml} / \mathrm{m}^{2} .{ }^{1}{ }^{18} \mathrm{LV}$ hypertrophy was defined as an LV mass index of more than $95 \mathrm{~g} / \mathrm{m}^{2}$ for women and more than $115 \mathrm{~g} / \mathrm{m}^{2}$ for men.

A medical history was taken and a physical examination was performed in all study patients. The clinical symptoms of HF were classified according to the New York Heart Association (NYHA). ${ }^{1}$ Routine laboratory tests were performed including the measurement of BNP levels (with a cut-off value of $\geq 35 \mathrm{pg} / \mathrm{ml}$ for chronic $\mathrm{HF}),{ }^{1}$ complete blood count, measurement of creatinine levels, glomerular filtration rate (GFR) using the Modification of Diet in Renal Disease formula, lipid levels, and thyroid-stimulating hormone levels. In addition, chest X-ray, the Bruce treadmill test for the diagnosis of CAD, and spirometry for a differential diagnosis of dyspnea were performed. The medical records of all patients were also reviewed.

The primary endpoint was the diagnosis of chronic HFPEF in patients with isolated relaxation abnormalities on the basis of the clinical presentation and imaging tests (ie, echocardiography and chest X-ray). The secondary endpoint was an increase in BNP levels to $35 \mathrm{pg} / \mathrm{ml}$ or higher in patients with HFPEF.

Statistical analysis A statistical analysis was conducted using the Statistica 7.0 PL software. Continuous variables were first evaluated for normal 
TABLE 1 Echocardiographic findings, brain natriuretic peptide levels, chest X-ray results, and symptoms of heart failure with preserved ejection fraction in patients with impaired left ventricular relaxation

\begin{tabular}{|c|c|c|c|c|}
\hline Variable & $\begin{array}{l}\text { All patients } \\
(n=210)\end{array}$ & $\begin{array}{l}\text { Men } \\
(n=89)\end{array}$ & $\begin{array}{l}\text { Women } \\
(n=121)\end{array}$ & $\begin{array}{l}P \text { value, } \\
\text { men vs } \\
\text { women }\end{array}$ \\
\hline $\mathrm{E} / \mathrm{A}$ ratio & $0.51 \pm 0.12$ & $0.54 \pm 0.12$ & $0.50 \pm 0.10$ & $<0.01$ \\
\hline $\mathrm{DT}, \mathrm{ms}$ & $\begin{array}{c}296.67 \\
\pm 35.64\end{array}$ & $\begin{array}{c}295.74 \\
\pm 34.73\end{array}$ & $\begin{array}{c}297.26 \\
\pm 31.62\end{array}$ & 0.9 \\
\hline LAVI, ml/m² & $32.74 \pm 6.70$ & $29.14 \pm 6.17$ & $32.40 \pm 6.29$ & 0.02 \\
\hline LAVI > $34 \mathrm{ml} / \mathrm{m}^{2}$ & $80(38)$ & $26(29)$ & $54(45)$ & 0.03 \\
\hline $\mathrm{E} / \mathrm{e}^{\prime}$ ratio & $9.30 \pm 2.64$ & $8.90 \pm 2.69$ & $9.74 \pm 2.75$ & $<0.01$ \\
\hline $\mathrm{E} / \mathrm{e}^{\prime}$ ratio $>8$ & $77(37)$ & $25(28)$ & $52(43)$ & 0.03 \\
\hline LVEF, \% & $64.52 \pm 3.45$ & $65.32 \pm 4.35$ & $59.39 \pm 3.30$ & 0.12 \\
\hline LV mass, $\mathrm{g} / \mathrm{m}^{2}$ & $110.27 \pm 32.0$ & $105.20 \pm 29.0$ & $110.00 \pm 30.0$ & 0.01 \\
\hline higher LV mass ${ }^{\mathrm{a}}$ & $79(38)$ & $26(29)$ & $53(44)$ & 0.04 \\
\hline $\mathrm{BNP}, \mathrm{pg} / \mathrm{ml}$ & $34.67 \pm 29.60$ & $29.01 \pm 24.12$ & $32.13 \pm 28.02$ & 0.001 \\
\hline $\mathrm{BNP}>35 \mathrm{pg} / \mathrm{ml}$ & $81(39)$ & $27(30)$ & $54(46)$ & 0.04 \\
\hline $\begin{array}{l}\text { pulmonary } \\
\text { congestion on } \\
\text { chest X-ray }\end{array}$ & $85(41)$ & $28(32)$ & $57(47)$ & 0.03 \\
\hline $\begin{array}{l}\text { symptoms of } \\
\text { HFPEF }\end{array}$ & $89(42)$ & $30(34)$ & $59(49)$ & 0.04 \\
\hline
\end{tabular}

Data are presented as mean \pm standard deviation or number (percentage) of patients.

a increased LV mass was considered as more than $95 \mathrm{~g} / \mathrm{m}^{2}$ for women and more than $115 \mathrm{~g} / \mathrm{m}^{2}$ for men

Abbreviations: BNP, brain natriuretic peptide; DT, deceleration time; HFPEF, heart failure with preserved ejection fraction; LAVI, left atrial volume index; LV, left ventricular; LVEF, left ventricular ejection fraction

TABLE 2 Independent predictors of heart failure with preserved ejection fraction in a multivariate regression model

\begin{tabular}{llll} 
Variable & $95 \% \mathrm{Cl}$ & OR & $P$ value \\
age, $\mathrm{y}$ & $1.07-1.25$ & 1.15 & $<0.01$ \\
\hline type 2 diabetes & $2.78-15.67$ & 6.65 & $<0.01$ \\
\hline $\mathrm{SBP} \geq 140 \mathrm{mmHg}$ & $2.16-14.36$ & 5.57 & $<0.01$ \\
\hline coronary artery disease & $2.17-13.75$ & 5.46 & $<0.01$ \\
\hline $\mathrm{GFR}<60 \mathrm{ml} / \mathrm{min} / 1.73 \mathrm{~m}^{2}$ & $1.11-2.89$ & 1.56 & 0.04 \\
\hline
\end{tabular}

Abbreviations: $\mathrm{Cl}$, confidence interval; $\mathrm{GFR}$, glomerular filtration rate; $\mathrm{OR}$, odds ratio; SBP, systolic blood pressure clinical, laboratory, and echocardiographic variables that showed an association with HFPEF in the univariate model and did not show significant correlations with another independent variables were included in the multiple regression analysis to determine the predictors of HFPEF.

RESULTS The study included 210 patients with hypertension and isolated relaxation abnormalities (women [58\%] at a mean age of $60.83 \pm 5$ years; men [42\%] at a mean age of $53.11 \pm 6.32$ years; $P<0.001$; mean age of the whole study group, $56.11 \pm 6.24$ years). In the whole study group, the mean systolic blood pressure was $130.56 \pm 14.67 \mathrm{mmHg}$, while mean diastolic blood pressure was $79.73 \pm 10.12 \mathrm{mmHg}$; most participants $(57 \%)$ had satisfactory blood pressure control. HFPEF was observed in $42 \%$ of the patients. It was observed more often in women than in men $(P=0.04)$. The mean values of systolic blood pressure in patients with HFPEF were higher $(135.72 \pm 17.45$ vs $130.12 \pm 12.3 \mathrm{mmHg} ; P<0.01)$ than in patients without HFPEF. Also diastolic blood pressure in HFPEF patients was higher than in individuals without HFPEF $(80.80 \pm 11.30$ vs $76.64 \pm 1.77 \mathrm{mmHg} P<0.02$ ). The results of imaging tests and BNP measurements as well as the number of patients with HF are presented in TABLE 1.

In patients with impaired relaxation and clinical symptoms of HFPEF, serum BNP levels were from 104.4 to $480.2 \mathrm{pg} / \mathrm{ml}$ (mean, $225 \pm 45.8$ $\mathrm{pg} / \mathrm{ml}$ ). Mild functional mitral regurgitation was observed in $88 \%$ of the patients with HFPEF and LAVI exceeding $34 \mathrm{ml} / \mathrm{m}^{2}$.

The most common clinical symptoms of HF were dyspnea and reduced exercise tolerance, which were observed in $89 \%$ of the patients, of whom about $78 \%$ were classified as NYHA class II and $11 \%$ - as NYHA class III.

The independent predictors of HFPEF in the multivariate regression model for the whole study group are presented in TABLE 2 .

HFPEF was more common in patients with type 2 diabetes ( $76 \%$ of the patients in comparison with $24 \%$ of nondiabetic patients; $P=0.01$ ). Diabetic patients, apart from diet, received pharmacological treatment. Metformin as the only hypoglycemic agent was administered in $52 \%$ of the patients. Sulfonylurea derivatives were used by $48 \%$ of the patients, while insulin treatment in combination with metformin-in $42 \%$. The most common insulin therapy was the 2-injection regimen. The differences between patients with and without diabetes are presented in TABLE 3.

The analysis of diastolic function parameters showed a positive correlation (both for women and men) between BNP levels and age ( $r=0.55$; $P<0.01)$, DT $(r=0.53 ; P<0.01), \mathrm{E} / \mathrm{e}^{\prime}(r=0.48$; $P<0.01)$, systolic blood pressure of $140 \mathrm{mmHg}$ or higher $(r=0.41 ; P<0.01)$, LAVI $(r=0.17 ; P<0.01)$, LV mass $(r=0.67 ; P<0.0001)$, and an insulin dose exceeding 80 units/day in diabetic patients $(r=$ 0.44; $P<0.01)$ as well as a negative correlation 
TABLE 3 Characteristics of patients with and without diabetes

\begin{tabular}{|c|c|c|c|}
\hline Variable & $\begin{array}{l}\text { Patients with } \\
\text { diabetes } \\
(n=140)\end{array}$ & $\begin{array}{l}\text { Patients without } \\
\text { diabetes } \\
(\mathrm{n}=70)\end{array}$ & $P$ value \\
\hline age, y & $60.82 \pm 4.86$ & $56.15 \pm 5.56$ & $<0.01$ \\
\hline $\mathrm{BMI}, \mathrm{kg} / \mathrm{m}^{2}$ & $30.68 \pm 3.67$ & $29.00 \pm 3.82$ & $<0.01$ \\
\hline hypertension & $140(100)$ & $70(100)$ & 1.0 \\
\hline SBP, mmHg & $139.83 \pm 17.87$ & $133.78 \pm 16.95$ & $<0.01$ \\
\hline $\mathrm{DBP}, \mathrm{mmHg}$ & $85.17 \pm 9.55$ & $77.74 \pm 10.77$ & $<0.01$ \\
\hline hyperlipidemia & $100(71.4)$ & $31(44.2)$ & $<0.01$ \\
\hline $\mathrm{GFR}, \mathrm{ml} / \mathrm{min} / 1.73 \mathrm{~m}^{2}$ & $80.06 \pm 24.80$ & $87.60 \pm 18.56$ & 0.03 \\
\hline GFR $<60 \mathrm{ml} / \mathrm{min} / 1.73 \mathrm{~m}^{2}$ & $60(43)$ & $14(20)$ & 0.01 \\
\hline coronary artery disease & $72(51)$ & $25(36)$ & 0.04 \\
\hline $\begin{array}{l}\text { history of myocardial } \\
\text { infarction }\end{array}$ & $23(16)$ & $10(14)$ & 0.8 \\
\hline history of stroke & $6(4)$ & $6(9)$ & 0.3 \\
\hline smoking & $30(21)$ & $13(19)$ & 0.8 \\
\hline ACEls & $132(94)$ & $53(76)$ & 0.01 \\
\hline diuretics & $123(88)$ & $33(47)$ & $<0.01$ \\
\hline calcium channel blockers & $102(73)$ & $44(63)$ & 0.18 \\
\hline$\beta$-blockers & $129(92)$ & $57(81)$ & 0.03 \\
\hline aspirin & $89(64)$ & $49(70)$ & 0.4 \\
\hline $\begin{array}{l}\text { angiotensin receptor } \\
\text { blockers }\end{array}$ & $2(1.4)$ & $15(21)$ & $<0.01$ \\
\hline statins & $135(96)$ & $59(84)$ & $<0.01$ \\
\hline fibrates & $4(3.0)$ & $2(3)$ & 0.7 \\
\hline
\end{tabular}

Data are presented as mean \pm standard deviation or number (percentage) of patients.

Abbreviations: ACEl, angiotensin-converting enzyme inhibitor; BMI, body mass index; DBP, diastolic blood pressure; others, see TABLE 2

TABLE 4 Independent predictors of heart failure with preserved ejection fraction in patients with type 2 diabetes and impaired left ventricular relaxation in a multivariate regression model

\begin{tabular}{llll} 
Variable & $95 \% \mathrm{Cl}$ & $\mathrm{OR}$ & $P$ value \\
age, $\mathrm{y}$ & $1.10-1.28$ & 1.18 & $<0.01$ \\
\hline $\mathrm{SBP}>140 \mathrm{mmHg}$ & $4.56-24.8$ & 10.66 & $<0.01$ \\
\hline coronary artery disease & $2.22-12.40$ & 5.25 & $<0.01$ \\
\hline $\mathrm{GFR}<60 \mathrm{ml} / \mathrm{min} / 1.73 \mathrm{~m}^{2}$ & $0.93-0.97$ & 0.95 & $<0.01$ \\
\hline increased $\mathrm{LV}$ mass, $\mathrm{g} / \mathrm{m}^{2}$ & $1.37-8.41$ & 3.40 & 0.01 \\
\hline
\end{tabular}

Abbreviations: see TABLES 1 and 2

with $\mathrm{E} / \mathrm{A}(r=-0.49 ; P<0.01)$ and body mass in$\operatorname{dex}(r=-0.50 ; P=0.01)$.

The independent predictors of HFPEF in the multivariate regression model in patients with diabetes are shown in TABLE 4.

DISCUSSION Studies published so far have indicated that, in patients with isolated diastolic dysfunction, the risk of $\mathrm{HF}$ is proportional to the degree of diastolic dysfunction. ${ }^{19-24} \mathrm{Howev}^{-}$ er, in our study, we observed HFPEF in $42 \%$ of the patients (mean age, $56.11 \pm 6.24$ years) with hypertension and the mildest form of diastolic dysfunction, namely, impaired relaxation. To the best of our knowledge, our study is the first to demonstrate the presence of HFPEF in patients with impaired relaxation, which was confirmed at the same time by different diagnostic methods. However, we believe that this phenomenon must have already been observed by practicing cardiologists. Our patients not only presented with subjective symptoms of HF (mainly dyspnea and reduced exercise tolerance) but also showed signs of pulmonary congestion, elevated LV end-diastolic pressure on echocardiography, and increased BNP levels.

Numerous studies have shown an association between an increase in the incidence of isolated HFPEF and aging. ${ }^{25-27}$ However, our study revealed that HFPEF may also develop in younger patients because the mean age of our subjects at diagnosis was 59 years, while the youngest patient was 45 years old. This indicates that the treatment of hypertension and related comorbidities may be insufficient, and physicians should focus on developing methods of assessing treatment efficacy individually in each patient.

It is well known that older age, hypertension, and CAD are common causes of HFPEF. In our study, all patients with impaired LV relaxation had hypertension and, additionally, some of them had CAD and diabetes. In most patients, hypotensive therapy was effective, but in patients with HFPEF, mean blood pressure values were higher than in those without HFPEF. The role of chronic heart ischemia as the cause of HFPEF was confirmed in other clinical studies even without concomitant impaired contractility. ${ }^{8}$ In our study, CAD was an independent predictor of HFPEF.

In our study, reduced GFR was also an independent predictor of HFPEF. Lower GFR values were observed more often in diabetic patients compared with nondiabetic ones $(P=0.01)$. The association between reduced GFR and increased severity of HF symptoms as well as increased incidence of HFPEF and HFREF has also been reported by other authors. ${ }^{28,29}$

We also showed a higher incidence of HFPEF in women, which may be explained by the fact that they were older and more often had obesity, renal failure, type 2 diabetes, higher blood pressure, and greater LV hypertrophy, all of which are known risk factors for HFPEF. In addition, most women in our study were postmenopausal, which might have been an additional risk factor for the development of HFPEF because of reduced vascular and heart muscle compliance due to lower estrogen levels. ${ }^{30-32}$

Another independent predictor of HFPEF is type 2 diabetes. In our study, diabetic patients constituted $68 \%$ of the study group. The etiology of HFPEF in patients with type 2 diabetes is complex. The available data indicate, among others, the role of chronic hyperglycemia, which may lead to cardiac fibrosis and secondary reduction in LV compliance. This in turn may manifest itself in the early stages only during exertion. ${ }^{32-34}$ However, in our study, patients with diabetes had a wide range of other possible causes of HFPEF 
apart from hyperglycemia, such as hypertension, obesity, CAD, LV hypertrophy, and impaired renal function, which makes it difficult to assess the role of abnormal glucose metabolism alone in the development of HFPEF. This might have been possible if the study included also patients with type 2 diabetes and no comorbidities. The lack of such patient subgroup in our study may be considered as one of the limitations; however, it was very difficult to identify such patients in clinical practice. In addition, in our study, all patients with diabetes were older, had greater LV hypertrophy, higher body mass index, and higher blood pressure despite a more frequent use of antihypertensive therapy, compared with nondiabetic patients. They also had a lower GFR and higher incidence of CAD. All these factors increased the risk of HFPEF in comparison with nondiabetic subjects in our study population.

Although our multivariate regression analysis did not show insulin therapy to be an independent predictor of HFPEF, we observed a positive correlation between an insulin dose $(>80$ units/day) and BNP levels. In particular, high levels of endogenous insulin in obese patients with type 2 diabetes who received insulin treatment may be one of the risk factors for HFPEF. Based on pathophysiological data, we believe that high insulin levels related to insulin resistance in type 2 diabetes in combination with exogenous insulin lead to hypercatecholaminemia, activation of the renin-angiotensin-aldosterone system, an increase in peripheral resistance, and heart overload. In turn, heart overload results in diastolic dysfunction and HFPEF. The relationship between chronic heart overload in diabetic patients treated with insulin and diastolic dysfunction was also discussed in a study by Konduracka et al. ${ }^{33}$

Recent data have shown that BNP levels are increased in patients with HF, which is especially important in the differential diagnosis of dyspnea. ${ }^{35}$ The degree of an increase in BNP levels was examined in different types of HF in a number of studies, and it is known that HFREF increases plasma BNP concentrations to a greater extent than HFPEF does. ${ }^{35-37}$ In our study, mean BNP levels in patients with symptoms of HFPEF were $225 \mathrm{pg} / \mathrm{ml}$, whereas in a study by Lubien et $a l,{ }^{37}$ mean BNP levels in patients with impaired relaxation and dyspnea were slightly higher than those in our study (about 310 pg/ $\mathrm{ml}$ ), which was probably related to older age of those patients compared with our population. On the other hand, in a review article, Dahlstörm ${ }^{38}$ stated that natriuretic peptides are not activated in patients with diastolic dysfunction in the form of impaired relaxation. Additionally, in our study, increased BNP levels correlated positively with echocardiographic markers of increased LV end-diastolic pressure, which, in combination with clinical presentation, proves the usefulness of this marker in the diagnosis of chronic HFPEF.
The presence of isolated HFPEF in a substantial number of patients with impaired relaxation indicates that this stage of diastolic dysfunction is not necessarily as mild as is commonly believed. It is important to intensify the treatment of any conditions leading to HF before any echocardiographic signs of diastolic dysfunction are observed. Not only the classification grades but also some diagnostic markers of HFPEF may vary between individual patients. Sometimes, the parameters are conflicting and there are variations between studies depending on the study population. In a recent study, Kuwaki et $\mathrm{al}^{39}$ investigated a group of patients in whom diastolic dysfunction could not be graded according to the standard classification on the basis of echocardiography, similarly to our patients. These patients had an E/A ratio of 0.75 or higher, DT exceeding $140 \mathrm{~ms}$, and an E/e' ratio of 10 or higher, so despite having mild diastolic dysfunction, they had a high probability of increased LV enddiastolic pressure. The authors postulated that a new degree of diastolic dysfunction should be recognized and emphasized that these patients have a serious prognosis with the risk of serious cardiovascular events and that such cases are not uncommon in clinical practice.

In conclusion, isolated impaired $\mathrm{LV}$ relaxation may be accompanied by HFPEF; therefore, the issue of whether this stage of diastolic dysfunction is relatively mild should be readdressed. Increased BNP levels in symptomatic patients with impaired relaxation prove the usefulness of this marker in the diagnosis of chronic HFPEF. In addition, because the modifiable predictors of HFPEF in patients with impaired LV relaxation include systolic blood pressure of 140 $\mathrm{mmHg}$ or higher, obesity, increased LV mass, impaired renal function (GFR $<60 \mathrm{ml} / \mathrm{min} / 1.73$ $\mathrm{m}^{2}$ ), CAD, and type 2 diabetes, prevention of all those possible causes of HF is necessary (mainly through lifestyle modification). Moreover, in patients who already suffer from those conditions, it is necessary to intensify the treatment so that the onset of diastolic dysfunction is delayed. In diabetic patients, a positive correlation between higher doses of insulin (> 80 units/day) and BNP levels requires further research.

Contribution statement $\mathrm{HB}$ conceived the idea for the study. HB and EK contributed to the design of the research. HB was involved in data collection. HB, EK, and GG analyzed the data. All authors edited and approved the final version of the manuscript.

\section{REFERENCES}

1 McMurray J, Adamopoulos S, Anker S, et al. ESC Guidelines for the diagnosis and treatment of acute chronic heart failure 2012. Eur Heart $\mathrm{J}$. 2012; 33: 1787-1847.

2 Sherif F, Nagueh SF, Appleton C, et al. Recommendations for the Evaluation of Left Ventricular Diastolic Function by Echocardiography. Eur J Echocardiogr. 2009; 10: 165-193.

3 Vasan RS, Larson MG, Benjamin EJ, et al. Congestive heart failure in subjects with normal versus reduced left ventricular ejection fraction: 
prevalence and mortality in a population-based cohort. J Am Coll Cardiol. 1999; 33: 1948-1955.

4 Smith GL, Masoudi FA, Vaccarino V, et al. Outcomes in heart failure patients with preserved ejection fraction: mortality, readmission, and functional decline. J Am Coll Cardiol. 2003; 41: 1510-1518.

5 Braksator W, Chybowska B. [Practical approach to evaluation of left ventricular diastolic dysfunction]. Kardiologia na co dzień. 2009; 4: 70-72. Polish.

6 Szczeklik A, Tendera M. [Cardiology: evidence-based medicine textbook]. Vol 2. Kraków, Poland: Medycyna Praktyczna; 2010: 714-723. Polish.

7 Wierzbowska-Drabik K, Kasprzak J. [Heart failure with preserved ejection fraction]. In: Pruszczyk P, Hryniewiecki T, Drożdż J, eds. [The Great Textbook of Internal Medicine: Cardiology. Part II]. Warsaw, Poland: Medical Tribune Polska; 2010: 35-40. Polish.

8 Sherazi S, Zaręba W. [Diastolic heart failure: predictors of mortality]. Folia Cardiologica Excerpta. 2011; 6: 168-179. Polish.

9 Mottram PM, Marwick TH. Assessment of diastolic function: what the general cardiologist needs to know. Heart. 2005; 91: 681-695.

10 Paulus WJ, Tschope C, Sanderson JE, et al. How to diagnose diastolic heart failure: a consensus statement on the diagnosis of heart failure with normal left ventricular ejection fraction by the heart Failure and Echocardiography Associations of the European Society of Cardiology. Eur Heart J. 2007; 28: 2539-2550.

11 Owan TE, Redfield MM. Epidemiology of diastolic heart failure. Prog Cardiovasc Dis. 2005; 47: 320-332.

12 Heart Failure Society of America; Lindenfeld J, Albert NM, Boehmer JP, et al. HFSA 2010 Comprehensive Heart Failure Practice Guideline. J Card Fail. 2010; 16: e1-194.

13 Lam CS, Donal E, Kraigher-Krainer E, Vasan RS. Epidemiology and clinical course of heart failure with preserved ejection fraction. Eur $\mathrm{J}$ Heart Fail. 2011; 13: 18-28.

14 Thomas MD, Fox KF, Coats AJ, Sutton GC. The epidemiological enig ma of heart failure with preserved systolic function. Eur J Heart Fail. 2004; $6 ; 125-136$.

15 Owan TE, Hodge DO, Herges RM, et al. Trends in prevalence and outcome of heart failure with preserved ejection fraction. N Engl J Med. 2006; 355: 251-259.

16 Mancia G, Fagard R, Narkiewicz K, et al. 2013 ESH/ESC Guidelines for the management of arterial hypertension. The Task Force for the management of arterial hypertension of the European Society of Hypertension (ESH) and of the European Society of Cardiology (ESC). J Hypertens. 2013; 31: 1281-1357.

17 Lang RM, Bierig M, Devereux RB, et al. Recommendations for chamber quantification: a report from the American Society of Echocardiography's Guidelines and Standards Committee and the Chamber Quantification Writing Group, developed in conjunction with the European Association of Echocardiography, a branch of the European Society of Cardiology. J Am Soc Echocardiogr. 2005; 18: 1440-1463.

18 Rigolli M, Whalley GA. Heart failure with preserved ejection fraction. J Geriatric Cardiol. 2013; 10: 369-376.

19 Pieske B. Heart failure with preserved ejection fraction - a growing epidemic or "The Emperor's New Clothes?". Eur J Heart Fail. 2011; 13: $11-13$.

20 Mahadevan G, Dwivedi G, Williams L, et al. Epidemiology and diagnosis of heart failure with preserved left ventricular ejection fraction: rationale and design of the study. Eur J Heart Fail. 2012; 14: 106-112.

21 Vogel MW, Slusser JP, Hodge DO, Chen CC. The natural history of preclinical diastolic dysfunction: a population-based study. Circ Heart Fail. 2012; 5: 144-151.

22 Borlaug BA, Paulus WJ. Heart failure with preserved ejection fraction: pathophysiology, diagnosis, and treatment. Eur Heart J. 2011; 32: 670-679. 23 Surdacki A, Dubiel JS. [Chronic heart failure with preserved ejection fraction]. Medycyna Praktyczna. 2010; 697-713. Polish.

24 Hummel YM, Voors AA. Grading diastolic left ventricular function. Eur J Heart Fail. 2011; 13: 698-699.

25 Cleland JGF, Tendera M, Adamus J, et al. PEP-CHF Investigators. Perindopril for eldery people with chronic heart failure: the PEP-CHF study. Eur J Heart Fail. 1999; 1: 211-217.

26 Granger Ch, Mc Murray J, Yusnf S, et al. Effects of candesartan in patients with chronic heart failure and reduced left-ventricular systolic function intolerant to angiotensin-converting-enzyme inhibitors: the CHARM-AIternative trial. The Lancet. 2003; 6: 772-776.

27 Massie BM, Carson PE, McMurray JJ, et al. Irbesartan in patients with heart failure and preserved ejection fraction. N Engl J Med. 2008; 359: 2456-2467.

28 Brett MV, Barron JT. Diastolic heart failure versus diastolic dysfunction: difference in renal function. Clin Cardiol. 2010; 33, 12: 770-774.

29 Moran A, Katz R, Smith NL, et al. Cystatin C concentration as a predictor of systolic and diastolic heart failure. J Card Fail. 2008; 14: 19-26.

30 Scantlebury DC, Borlaug BA. Why are women more likely than men to develop heart failure with preserved ejection fraction? Curr Opin Cardiol. 2011; 26: 562-568.
31 Duprez D, Jacobs D. Atrial stiffness and left ventricular diastolic function. 2010; 60: 283-284.

32 Milewska A, Krauze T, Piskorski J, et al. Association between high arterial stiffness andleft ventricular filling pressures in patients with acute myocardial infarction. Pol Arch Med Wewn. 2015; 125: 814-822.

33 Konduracka E, Gackowski A, Rostoff $P$, et al. Diabetes-specific cardio myopathy in type 1 diabetes mellitus: no evidence for its occurrence in the era of intensive insulin therapy. Eur Heart J. 2007; 28: 2465-2471.

34 Wierzbowska-Drabik K, Hamala P, Kasprzak DJ. Delayed longitudinal myocardial function recovery after dobutamine challenge as a novel presentation of myocardial dysfunction in type 2 diabetic patients without an giographic coronary artery disease. Eur Heart J Cardiovasc Imaging. 2015; 16: 676-683.

35 Solnica B. Biomarkers in heart failure: ready for use? Pol Arch Med Wewn. 2015; 125; 398-399.

36 Davis RC, Hobbs FD, Lip GY. ABC of heart failure. History and epidemiology. BMJ. 2000; 320: 39-42.

37 Lubien E, De Maria A, Krishnaswamy P. Utility of B-natriuretic peptide in detecting diastolic dysfunction comparison with Doppler velocity recordings. Circulation. 2002; 105: 595-601.

38 Dahlström U. Can natriuretic peptides be used for the diagnosis of diastolic heart failure? Eur J Heart Fail. 2004; 6: 281-287.

39 Kuwaki $\mathrm{H}$, Takeuchi $\mathrm{M}$, Chien-Chia $\mathrm{Wu} \mathrm{V}$, et al. Redefining diastolic dysfunction grading. Combination of $\mathrm{E} / \mathrm{A} \leq 0.75$ and deceleration time $>140$ $m s$ and $E / E^{\prime} \geq 10$. JACC Cardiovasc Imaging. 2014; 7: 749-758. 


\title{
Występowanie przewlekłej niewydolności serca z zachowaną frakcją wyrzutową mięśnia lewej komory u osób z nadciśnieniem tętniczym i izolowaną łagodną postacią dysfunkcji rozkurczowej
}

\author{
Halina Brzyżkiewicz ${ }^{1}$ Ewa Konduracka², Grzegorz Gajos², Marianna Janion³ \\ 1 II Klinika Kardiologii, Świętokrzyskie Centrum Kardiologii, Kielce \\ 2 Klinika Choroby Wieńcowej i Niewydolności Serca z Pododdziatem Intensywnej Opieki Kardiologicznej, \\ Uniwersytet Jagielloński, Collegium Medicum, Krakowski Szpital Specjalistyczny im. Jana Pawła II, Kraków \\ 3 II Klinika Kardiologii, Świętokrzyskie Centrum Kardiologii, Wydział Nauki o Zdrowiu, Uniwersytet Jana Kochanowskiego, Kielce
}

\section{SŁOWA KLUCZOWE}

niewydolność serca z zachowaną frakcją wyrzutową, zaburzenia relaksacji lewej komory
Adres do korenspondencji: Dr n. med. Halina Brzyżkiewicz, ॥l Klinika Kardiologii,

Świętokrzyskie Centrum Kardiologii, ul. Grunwaldzka 45, 25-736 Kielce, tel.: 413671456 , e-mail: brzyzkiewicz@op.pl Praca wpłynęła: 24.11.2015. Przyjęta do druku: 07.12.2015. Publikacja online: 22.01.2016. Nie zgtoszono sprzeczności interesów.

Pol Arch Med Wewn. 2016; 126 (1-2): $12-18$

Copyright by Medycyna Praktyczna, Kraków 2016

\section{STRESZCZENIE}

WPROWADZENIE Niewydolność serca z zachowaną frakcją wyrzutową (heart failure with preserved ejection fraction - HFPEF) pozostaje wyzwaniem w praktyce klinicznej. Rokowanie pacjentów z HFPEF jest podobne lub tylko nieznacznie lepsze w porównaniu do pacjentów z niewydolnością serca z obniżoną frakcją wyrzutową (heart failure with reduced ejection fraction - HFREF). Zaburzenia relaksacji są najłagodniejszą postacią dysfunkcji rozkurczowej, której nie powinny towarzyszyć objawy HFPEF.

CELE Celem badania była ocena występowania przewlekłej HFPEF u osób z nadciśnieniem tętniczym i izolowaną łagodną postacią dysfunkcji rozkurczowej.

PACJENCI I METODY W badaniu przekrojowym wzięło udział 210 pacjentów (średnia wieku 56,11 $\pm 6,24$ roku; 58\% kobiet) z izolowanymi zaburzeniami relaksacji mięśnia lewej komory i nadciśnieniem tętniczym. Dodatkowo w badanej grupie wyodrębniono chorych z cukrzycą typu 2 w celu porównania częstości występowania HFPEF z pacjentami bez cukrzycy. HFPEF była rozpoznawana, kiedy kliniczne objawy niewydolności serca wspótwystępowały z echokardiograficznymi wskaźnikami podwyższonego ciśnienia rozkurczowego lewej komory, z cechami zastoju w krążeniu płucnym w RTG klatki piersiowej lub ze zwiększonym stężeniem peptydu natriuretycznego (brain natriuretic peptide - BNP).

WYNIKI HFPEF rozpoznano u $42 \%$ badanych z zaburzeniami relaksacji. Podwyższony indeks objętości lewego przedsionka $\left(>34 \mathrm{ml} / \mathrm{m}^{2}\right)$ stwierdzono u $38 \%$ badanych, wskaźnik E/e' $>8-\mathrm{u} 37 \%$, zwiększone stężenie BNP - u 39\%, natomiast cechy zastoju w krążeniu płucnym w RTG klatki piersiowej - u $41 \%$. Niezależnymi predykatorami HFPEF były: wiek, skurczowe ciśnienie tętnicze krwi $\geq 140 \mathrm{~mm} \mathrm{Hg}$, cukrzyca typu 2, choroba wieńcowa oraz oszacowana wielkość przesączania kłębuszkowego $<60 \mathrm{ml} / \mathrm{min} / 1,73 \mathrm{~m}^{2}$. U pacjentów z cukrzycą wykazano dodatnią korelację między dawką insuliny $>80 \mathrm{j}$./d a stężeniem BNP. WNIOSKI Pacjenci z izolowanymi zaburzeniami relaksacji są niejednorodną klinicznie grupą, gdyż u części z nich występują objawy HFPEF, którym towarzyszy zwiększenie stężenia BNP. Dlatego należy zrewidować czy ten stopień dysfunkcji rozkurczowej rzeczywiście jest łagodny oraz podkreślić, że ci pacjenci mają poważne rokowanie z ryzykiem rozwoju niewydolności serca. U pacjentów z cukrzycą dodatnia korelacja pomiędzy wysoką dawką insuliny a stężeniem BNP wymaga dalszych badań. 